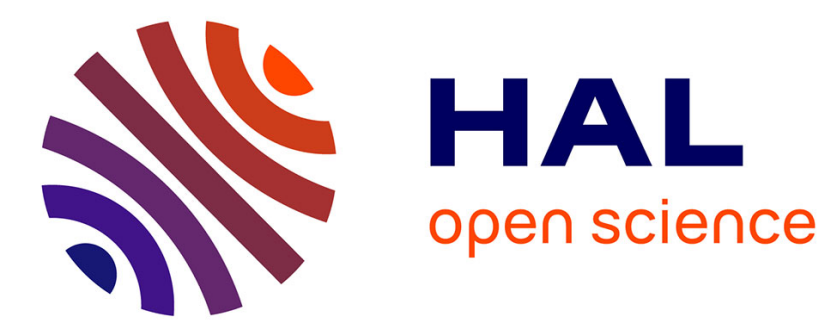

\title{
Improving the solar zenith angle dependence of broadband UV radiometers calibration
}

M. L. Cancillo, A. Serrano, M. Antón, J. A. García, J. M. Vilaplana

\section{To cite this version:}

M. L. Cancillo, A. Serrano, M. Antón, J. A. García, J. M. Vilaplana. Improving the solar zenith angle dependence of broadband UV radiometers calibration. Atmospheric Chemistry and Physics Discussions, 2007, 7 (6), pp.17873-17892. hal-00303210

\section{HAL Id: hal-00303210 https://hal.science/hal-00303210}

Submitted on 13 Dec 2007

HAL is a multi-disciplinary open access archive for the deposit and dissemination of scientific research documents, whether they are published or not. The documents may come from teaching and research institutions in France or abroad, or from public or private research centers.
L'archive ouverte pluridisciplinaire HAL, est destinée au dépôt et à la diffusion de documents scientifiques de niveau recherche, publiés ou non, émanant des établissements d'enseignement et de recherche français ou étrangers, des laboratoires publics ou privés. 


\section{Improving the solar zenith angle dependence of broadband UV radiometers calibration}

\section{L. Cancillo ${ }^{1}$, A. Serrano ${ }^{1}$, M. Antón ${ }^{1}$, J. A. García ${ }^{1}$, and J. M. Vilaplana ${ }^{2}$}

${ }^{1}$ Departamento de Física, Universidad de Extremadura, 06071 Badajoz, Spain

${ }^{2}$ INTA Departamento de Observación de la Tierra, Teledetección y Atmósfera, ESAt, "EI Arenosillo", Huelva, Spain

Received: 28 November 2007 - Accepted: 28 November 2007 - Published: 13 December 2007

Correspondence to: M. L. Cancillo (mcf@unex.es)

Improving the broadband UV radiometers calibration

M. L. Cancillo et al.

Title Page

Abstract Introduction

Conclusions

Tables References

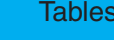

Figures

14 I

4

Back 


\section{Abstract}

This paper focusses on the proposal of a new method for the calibration of broadband ultraviolet radiometers. The advantage of the method proposed is the accurate modelling of the dependence on the solar zenith angle. The new model is compared with

other one-step calibration methods and with the two-step method, which requires the knowledge of the actual response of the broadband radiometer. For this purpose, three broadband radiometers are calibrated against a spectrophotometer of reference. The new method is validated comparing its predictions with the spectrophotometer measurements using an independent data set.

\section{Introduction}

In last decades there has been an increasing interest in monitoring and obtaining reliable UV values measured at surface. For this purpose, the use of broadband instruments to measure erythemal-weighted irradiance is widely extended due to their low cost and easy maintenance. In fact, they have been recommended by WMO as adequate instruments for monitoring UV, detecting trends, and establishing its climatology (WMO, 1998). However, an effective detection of trends and a suitable characterisation of the variablility of UV radiation require very accurate measurements and, therefore, a regular and careful calibration of the instruments is needed in order to reduce the uncertainty and to account for possible drifts.

The usual methodology for absolute calibration of broadband radiometers is to compare its electrical output voltage to the irradiance measured by a spectrophotometer taken as reference. This comparison technique has been used for more than ten years (Bodhaine et al., 1998; Leszczynski et al., 1998; Mayer and Seckmeyer, 1996; Vilaplana et al., 2006) and it is recommended by the WMO's Global Atmosphere Watch 25 (GAW) programme (WMO, 1996).

The models proposed for this inter-calibration process can be grouped in one-step

\section{Improving the} broadband UV radiometers calibration

M. L. Cancillo et al.

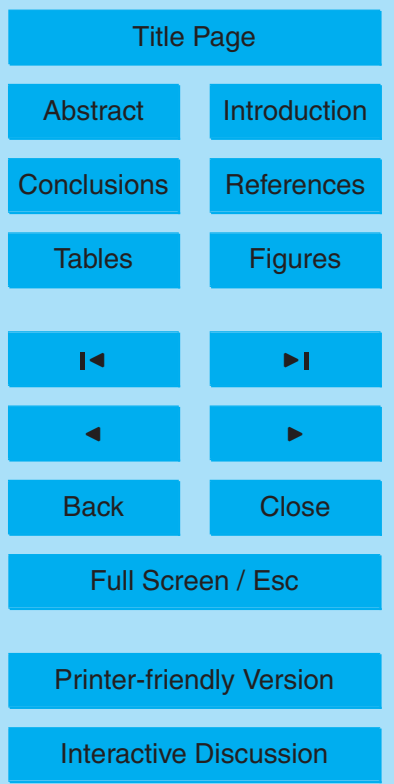


and two-step methods (Bais et al., 1999). In one-step methods, the calibration factor is directly obtained from the comparison between the output signal of the broadband radiometer and the erythemally integrated spectral irradiance given by the spectrophotometer. In two-step methods the calibration process requires two steps: firstly, the 5 actual spectral response of the broadband radiometer is applied to the spectrophotometer's measurements to obtain the absolute calibration factor and, secondly, a radiative transfer model is used to determine a matrix calibration which account for factor dependence on ozone and solar zenith angle. Finally, the definitive calibration factor is obtained as the product of the absolute factor and the calibration matrix.

10 Although the two-step method is recommended by several organizations responsible for calibration protocols, because of its higher accuracy, it has several disadvantages such as the need of knowing the actual spectral response function of the broadband radiometer and the ozone amount over the measuring site, which are often not available. Consequently, broadband radiometers are usually calibrated by means of a one-step method (Bodhaine et al., 1998; Leszczynski et al., 1998; Bais et al., 1999).

Regarding the angular behaviour, Cancillo et al. (2005) evidenced the inaccuracy of the more generally used one-step methods: ratio and first-order (Leszczynski et al., 1998; Lantz et al., 1999; Oppenrieder et al., 2003; Bodhaine et al., 1998; Grainger et al., 1993; Nunez et al., 1997). Although a second-order method improving this angular characterization was proposed, certain dependence with the solar zenith angle still remains for those cases with low solar elevations.

Thus, the present paper aims at improving the broadband radiometer's calibration methodology. More specifically, the purpose of this article is to analyze the dependence of the one-step methods on the solar zenith angle and to propose a new version of the one-step methods, named "angular method", which definitely account for the solar zenith angle dependence along the complete angle ranges.

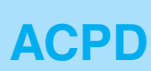

7, 17873-17892, 2007

\section{Improving the}

broadband UV

radiometers

calibration

M. L. Cancillo et al.

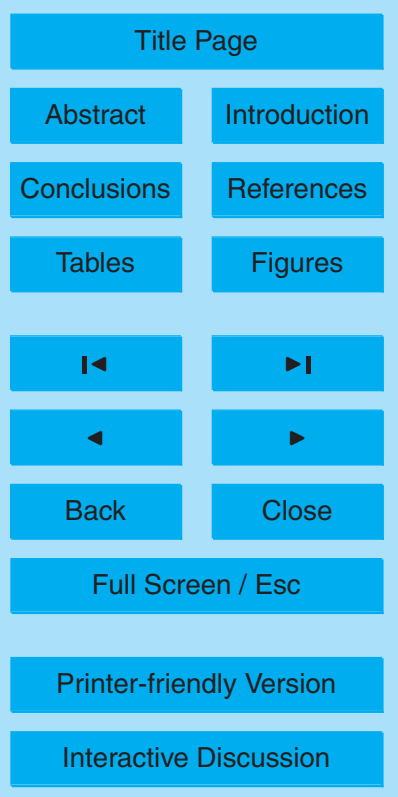




\section{Instrumentation and data}

Three broadband radiometers were used in this study. They are UV-S-E-T model, erythema weighted and manufactured by Scintec-Kipp \& Zonen. The instruments have been calibrated against a spectrophotometer of reference. This instrument consists of

5 a Brewer MK-III double monochromator, manufactured by Kipp \& Zonen and installed at the Atmospheric Sounding Station (ESAt), which belongs to the National Institute of Aerospace Technology (INTA). It is located at El Arenosillo in Huelva, Spain $\left(37.1^{\circ} \mathrm{N}\right.$, $6.7^{\circ} \mathrm{W}, 20 \mathrm{~m}$ a.s.I.). This centre is integrated in the Global Ozone Observing System (GO3OS) of the Global Atmosphere Watch (GAW) and the calibration of the spec-

10 trophotometer and its measurement procedures are standardized by the WMO quality assurance. This location has optimum conditions for radiometric observations such as a high number of clear days per year, an open horizon in all directions, and a uniform albedo all throughout the year.

The calibration campaign reported in this work took place from 30th September to

27 October 2005, just after the calibration of the Brewer instrument taken as reference. This instrument is itself calibrated every two years by its comparison to the travelling standard (Brewer \#017) from the International Ozone Services (IOS, Canada). Thus, its reliability is highly guaranteed.

Several authors have reported that non ideal cosine response represents one of the most important causes of uncertainty for spectroradiometric measurements (Gröbner et al., 1996). Brewer data used in this paper have been cosine response corrected with a method based in the studies of Fioletov et al. (2002) and Bernhard et al. (2002). A detailed description of this procedure can be found in the work of Antón et al. (2007).

The UV erythemal radiation (UVER) measurements given by the broadband radiometers were sampled every ten seconds and recorded as one-minute mean voltages on a Campbell CR10X data adquisition system.

The internal temperature, thermoelectrically stabilized at $25^{\circ} \mathrm{C}$, is continously monitored and the detector's internal humidity status is also supervised in order to avoid

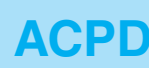

7, 17873-17892, 2007

\section{Improving the} broadband UV radiometers calibration

M. L. Cancillo et al.

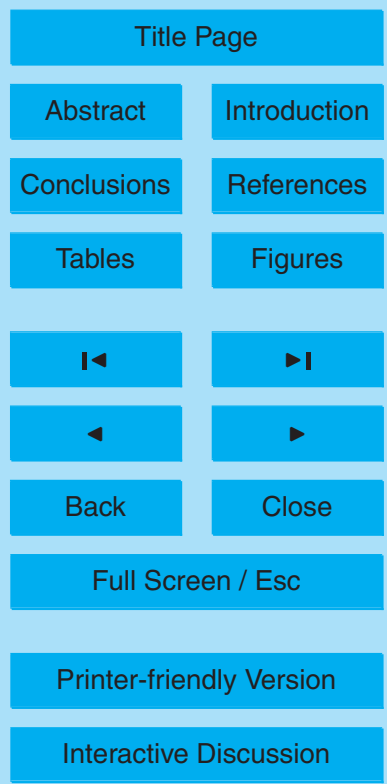


possible variations in the spectral sensitivity due to changes in these variables.

In this study, $733 \mathrm{~min}$ average data were used, corresponding to solar zenith angles up to $80^{\circ}$. To obtain the values of the coefficients of the models a subset of $77 \%$ of the whole data set (564 data randomly selected) was selected and the remaining $23 \%$ 5 (169 data) was considered as for the validation of the models.

The total ozone amount ranged from 260 to $311 \mathrm{DU}$ during the period of the campaign, with $285 \mathrm{DU}$ as the average value. Although the ozone variation during the measurement campaign doesn't strictly cover the evolution during the whole year, it can be considered representative of a long period within the year since $48 \%$ of the days for the 8 y period 1998-2005 at El Arenosillo have daily mean ozone values within the interval 260-311 DU.

\section{Calibration methods}

The calibration against a Brewer as the reference instrument requires a pre-process of its spectral measurements in order to build erythemally weighted ultraviolet irradiance simultaneous to the broadband measurements.

Firstly the spectrophotometer measurements' range has to be expanded from $363 \mathrm{~nm}$ (actual limit of the measurements of the Brewer) up to $400 \mathrm{~nm}$, which is the upper limit of the wavelengths measured by broadband radiometers. This calculation requires the use of a radiation transfer code; UVSPEC/libRadtran model (Mayer and Kylling, 2005) was used for this aim.

Secondly, simultaneous records of the same duration have to be obtained. For this goal, the broadband radiometer voltages were averaged along the $4.5 \mathrm{~min}$ period which takes each Brewer scan.

In order to analyze the models, the root mean square error (RMSE) was evaluated 25 for each of them and in the polynomial models, the coefficient of determination $\left(R^{2}\right)$ of the regression analysis and the standard error (SE) of the regression coefficients were also calculated.
Improving the broadband UV radiometers calibration

M. L. Cancillo et al.

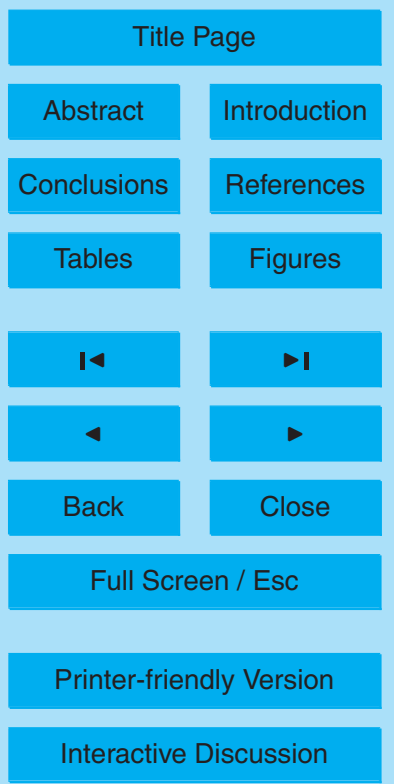


The new one-step method proposed was validated by comparing the model's UVER estimations with those provided by the two-steps model for an independent validation set. For this goal, the mean bias error (MBE) and the mean absolute bias error (MABE) were calculated.

\section{$5 \quad 3.1$ Former one step methods analysed}

The two one-step methods more extensively cited in bibliography are the ratio model (WMO, 1996 ; Leszczynski et al., 1998; Bais et al., 1999) and the first order model (Bodhaine et al., 1998; Grainger et al., 1993; Nunez et al., 1997).

In the first one, the calibration coefficient $\left(C F_{r}\right)$ is obtained through the averaged ratio between the UVER ${ }^{\text {Brewer }}$ values (erythemaly weighted) and the broadband voltages $V_{i}$ :

$C F_{r}=\frac{1}{N} \sum_{i=1}^{N} \frac{\text { UVER }_{i}^{\text {Brewer }}}{\mathrm{V}_{i}}$,

and, in the second one, the calibration coefficient $\left(C F_{f}\right)$ results from the linear regression between the UVER ${ }^{\text {Brewer }}$ values (erythemaly weighted) and voltages $\mathrm{V}_{i}$ :

$\mathrm{UVER}_{i}^{\mathrm{Brewer}}=C F_{f} \mathrm{~V}_{i}$.

15 Cancillo et al. (2005) proposed a second-order method, with two coefficients:

$\mathrm{UVER}_{i}^{\text {Brewer }}=C F_{s 1} \mathrm{~V}_{i}+C F_{s 2} \mathrm{~V}_{i}^{2}$

obtaining $C F_{s 1}$ and $C F_{s 2}$ coefficients through a regression analysis.

\subsection{New method proposed}

It is well known that the calibration coefficients are highly influenced by the solar zenith
ACPD

7, 17873-17892, 2007

\section{Improving the} broadband UV radiometers calibration

M. L. Cancillo et al.

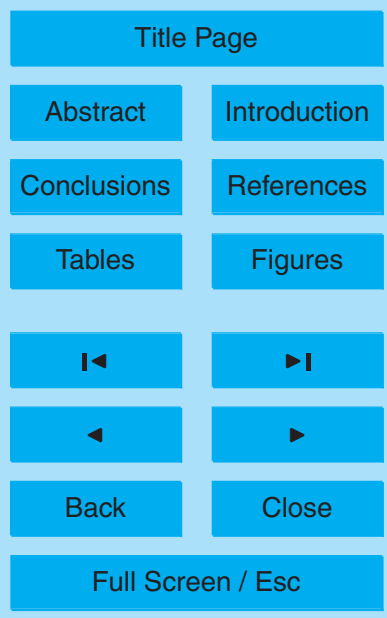

Printer-friendly Version

Interactive Discussion 
explicitly takes into account the solar zenith angle $(\theta)$ in the mathematical expression as follows:

$\mathrm{UVER}_{i}^{\text {Brewer }}=C_{1} \mathrm{~V}_{i}+C_{2} \mathrm{~V}_{i} \cos \theta_{i}$

ACPD

where $U_{V E R}{ }^{\text {Brewer }}$ represents Brewer erythematic irradiance, $\mathrm{V}$ is the output voltage of 5 broadband radiometer and $C_{1}$ and $C_{2}$ the regressión coefficients.

The advantage of this method is that greatly improves greatly the results obtained by former one-step methods while keeping the operational character of the one-step methodology.

\subsection{Two steps method}

10 This calibration method is more complex than those of one-step analyzed in former sections. It requires the actual spectral response function $\left(\mathrm{RSE}_{A}\right)$ of the broadband radiometer and the ozone amount and solar zenith angle. The complete description is beyond the scope of this paper, but it can be found in the work of Hülsen and Gröbner (2007).

15 The first step in the procedure consists in applying the $\mathrm{RSE}_{A}$ of the instrument to the spectral values of the Brewer spectrorradiometer to obtain the absolute calibration factor of each instrument $(\mathrm{K})$. This factor is obtained as the slope of the lineal regression between the output voltage of the instrument and the UV irradiance calculated by the integration of the Brewer spectral irradiance weighted by the $\mathrm{RSE}_{A}$ of the broadband radiometer.

In a second step, it is necessary to use a radiative transfer model in order to estimate the spectral UV irradiance values. Subsequently the ratio between the irradiance weighted by the $\mathrm{RSE}_{A}$ of the broadband radiometer and the UV irradiance weighted by the CIE spectral response is calculated. This ratio is strongly dependent on ozone amount and solar zenit angle. This dependence is taken into account by using a calibration matrix $(\mathrm{Ci}([\mathrm{O} 3], \theta)$. The radiative transfer model used in this study is the

Improving the

broadband UV

radiometers

calibration

M. L. Cancillo et al.

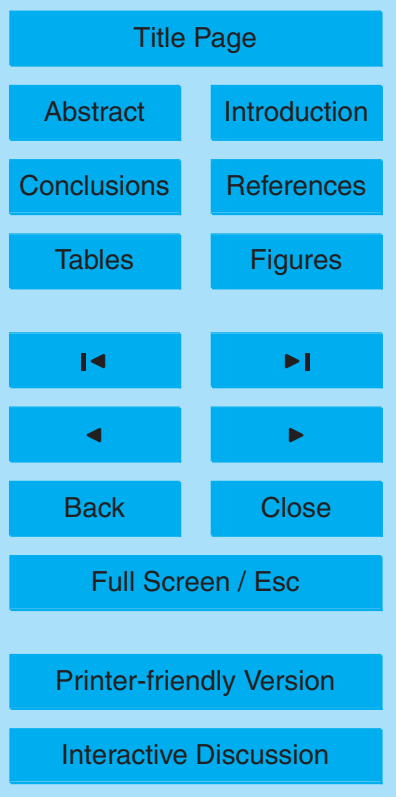

EGU 
UVSpec/libRadtran (Mayer and Kylling, 2005) with values of solar zenith angles between $0^{\circ}$ y $90^{\circ}$ by steps of $5^{\circ}$ and total ozone values between 200 and $400 \mathrm{DU}$ by steps of $10 \mathrm{DU}$.

Finally, the calibration factor $F_{i}$ for each UV voltage of broadband instrument is ob5 tained as follows:

$F_{i}\left(\left[O_{3}\right], \theta\right)=\mathrm{KC}_{i}\left(\left[\mathrm{O}_{3}\right], \theta\right)$,

and the erythemal radiance is obtained as

UVER $=\mathrm{V}_{i} F_{i}\left(\left[O_{3}\right], \theta\right)$.

\section{Results and discussion}

10 Using the methods described above, the results given by the diferent methods are shown in this section.

Figure 1 evidences the need of an individual calibration for each instrument. The UVER values obtained applying the manufacturer coefficients together with the measurements of the reference instrument (Brewer spectrophotometer) on 4 October 2005 are presented in the same figure. The three broadband radiometers overestimated the values given by the spectrorradiometer. This overestimation is even higher than $50 \%$ at solar noon.

In order to obtain the best calibration, the different methods presented in the former section were applied and analyzed. The root mean square error (RMSE) was evaluated for each model.

Table 1 shows the calibration factors estimated by the ratio model for the three broadband UV radiometers, with the standard errors of the coefficients (SE) and the RMSE values. All the calibration factors obtained are lower than the one provided by the manufacturer, which is the same for the three instruments $\left(0.1735 \mathrm{~W} / \mathrm{m}^{2} \mathrm{~V}\right)$. These values

Improving the broadband UV radiometers calibration

M. L. Cancillo et al.

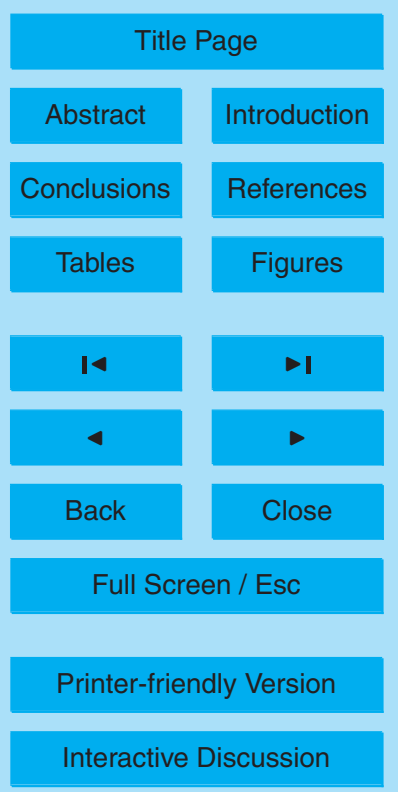


range between $54 \%$ and $59 \%$ lower than the original. On the other hand, RMSE values are also lower, having been reduced in more than $0.040 \mathrm{~W} / \mathrm{m}^{2}$ respect to the values obtained with the manufacturer coefficients.

Tables 2, 3 and 4 present the calibration factors estimated by the first-order model, 5 second-order model and angular model, respectively. The standard errors, root mean square errors and the regression coefficients of determination are also presented for each case. The first and the second-order models present better results than the ratio model (RMSE values lower) but the best behaviour is provided by the new method proposed; the angular method, where the reduction of RMSE values respect to the 10 ratio model reaches the $60 \%$. This improvement is justified because the angular model suitably accounts for the great part of the solar zenith angle dependence of the coefficients.

Figure 2 shows the evolution of the relative differences between irradiance measured by Brewer spectrophotometer and the irradiance estimated by broadband radiometer 15 \#1 using the four one-step models. The points represented correspond to the averaged differences obtained for SZA intervals of $1^{\circ}$. It is observable that the best results are obtained by the angular model, which presents very low differences in the whole range of solar zenith angles.

All the differences are bounded by $(-13 \%, 41 \%)$ for the ratio model, by $(-8 \%, 50 \%)$ in 20 the first order model and by $(-8 \%, 27 \%)$ in the second order model. These differences are considerately reduced in the angular method, where the limits of the interval for the differences are reduced to $(-5 \%, 7 \%)$ and if only SZA values up to $60^{\circ}$ are considered, the interval for the differences is still lower (-4\%, 3\%). Radiometers \#2 and \#3 showed very similar behaviour.

25 Thus, it is clear that the angular method proposed improves greatly the results obtained by the other three one-step models, mainly regarding the solar zenith angle dependence.

In order to compare the results of this method with the two steps procedure, a linear regression was performed between UVER values obtained applying both calibration

Improving the

broadband UV

radiometers

calibration

M. L. Cancillo et al.

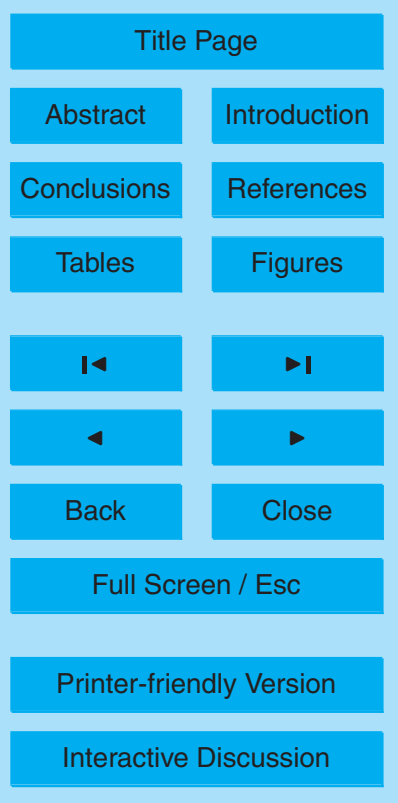

\section{1}


procedures. For this analysis a subset with 169 data, independent of the used for the fitting of the models, was used. Figure 3 shows the result of this fitting jointly with the $1: 1$ line for \#1 radiometer. As well, Table 5 presents the regression results. It is observable that the slopes are very close to 1 for the three radiometers presenting very 5 low relative errors. The determination coefficients are higher than 0.99 in all the cases. Also, the MABE (mean absolute bias error) has low values (about $3 \%$ ). The positive (negative) sign of MBE (mean bias error) indicates that UVER values obtained using the angular method overestimates (underestimates) the UVER values obtained applying the two steps procedure. All these results indicate the good agreement between both methods.

\section{Conclusions}

Comparison with measurements from a well calibrated spectrophotometer of reference evidenced the inaccuracy of the calibration coefficients provided by the manufacturers and the need to individually calibrate each broadband radiometer.

15 Regarding the performance of the calibration methods it must be noted that the widely used one-step methods, although giving more accurate values those provided by manufacturers, do not suitably reflect the angular dependence with the solar elevation. In this sense, the two-order and the angular methods mean an important improvement in order to obtain reliable irradiance values. The former suitably describes the angular dependence for solar zenith angles up to $60^{\circ}$. The latter consist in the best option, not only improving the performance of the second-order method, but also giving reliable irradiance values throughout the whole range of solar zenith angles.

Acknowledgements. This work has been partially granted by the Spanish "Ministerio de Educación y Ciencia" with project CGL2005-05693-C03-03 and by the "Junta de Extremadura" 25 ("Consejería de Infraestructuras y Desarrollo Tecnológico" and "Consejería de Sanidad y Consumo").

Improving the broadband UV radiometers calibration

M. L. Cancillo et al.

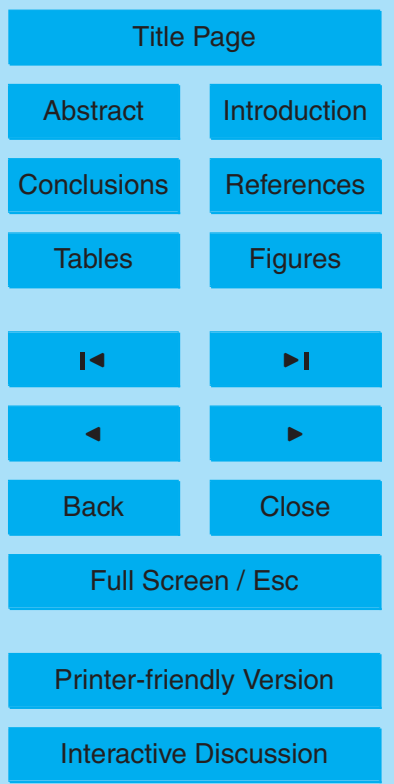




\section{References}

Antón, M., Cachorro, V. E., Vilaplana, J. M., Krotkov, N. A., A. Serrano, A., Toledano, C., de la Morena, B., and Herman, J. R. : Total ozone mapping spectrometer retrievals of noon erythemal-CIE ultraviolet irradiance compared with Brewer ground-based measurements at El Arenosillo (southwestern Spain). J. Geophys. Res., 112, doi:10.1029/2006JD007254, 2007.

Bais, A., Topaloglou, C., Kazadtzis, S., Blumthaler, M., Schreder, J., Schmalwieser, A., Henriques, D., and Janouch, M.: Report of the LAP/COST/WMO intercomparison of erythemal radiometers, Technical Report TD 1051, WMO/GAW, 1999.

Bernhard, G., Booth, C., and Ehramjian, J.: The quality of data from the National Science Foundations's UV Monitoring Network for Polar Regions. Remote Sensing of the Atmosphere, Ocean, Environment and Space, 4896, SPIE, 79-93, 2002.

Bodhaine, B. A., Dutton, E. G., McKenzie, R. L., and Johnston, P. V.: Calibrating broad-band UV instruments: Ozone and solar zenith angle dependence, J. Atmos. Ocean. Tech., 15, 916-926, 1998.

Cancillo, M. L., Serrano, A., Antón, M., García, J. A., Vilaplana, J. M., and de la Morena, B.: An improved outdoor calibration procedure for broadband ultraviolet radiometers, Photochem. Photobiol., 81, 860-865, 2005.

Fioletov, V., Kerr, J., Wardle, D., Krotkov, N., and Herman, J.: Comparison of Brewer ultraviolet irradiance measurements with TOMS satellite retrievals. Opt. Eng., 41, 3051-3061, 2002.

Grainger, R. G., Basher, R. E., and McKenzie, R. L.: UV-B Robertson-Berger meter characterization and field calibration. Appl. Opt., 32, 343-349, 1993.

Gröbner, J., Blumthaler, M., and Ambach, W.: Experimental investigation of spectral global irradiance measurements errors due to a non ideal cosine response, Geophys. Res. Lett., 23, 2493-2496, 1996.

Hülsen, G. and Gröbner, G.: Characterization and calibration of ultraviolet broadband radiometers measuring erythemally weighted irradiance. Appl. Opt., 46, 5877-5886, 2007.

Lantz, K., Disterhoft, P., DeLuisi, J. J., Early, E., Thompson, A., Bigelow, D., and Slusser, J.: Methodology for deriving clear-sky erythemal calibration factors for UV broadband radiometers of the U.S. central UV calibration facility, J. Atmos. Ocean. Tech., 16, 1736-1752, 1999.

Leszczynski, K., Jokela, K., Ylianttila, L., Visuri, R., and Blumthaler, M.: Erythemally weighted radiometers in solar UV monitoring: results from the WMO/STUK intercomparison, Pho-

\section{Improving the broadband UV radiometers calibration}

M. L. Cancillo et al.

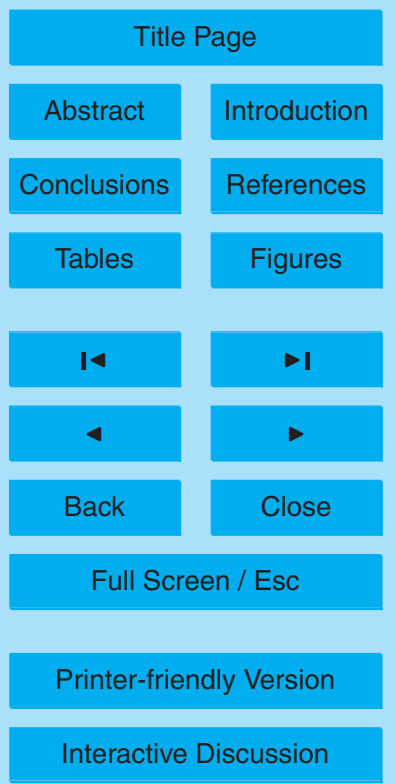


tochem. Photobiol., 67(2), 212-221, 1998.

Mayer, B. and Kylling, A.: The libRadtran software package for radiative transfer calculations description and examples of use, Atmos. Chem. Phys., 5, 1319-1381, 2005,

http://www.atmos-chem-phys.net/5/1319/2005/.

5 Mayer, B. and Seckmeyer, G.: All-weather comparison between spectral and broad-band (Robertson-Berger) UV measurements, Photochem. Photobiol., 64, 792-799, 1996.

Nunez, M., Michael, K., Turner, D., Wall, M., and Nilsson, C.: A satellite-based climatology of UV-B irradiance for antarctic coastal regions, Int. J. Climatol., 17, 1029-1054, 1997.

Oppenrieder, A., Hoeppe, P., Koepke, P., Reuder, J., Schween, J., and Schreder, J.: Simplified calibration for broadband solar ultraviolet radiation measurements, Photochem. Photobiol., 78(6), 603-606, 2003.

Vilaplana, J. M., Cachorro, V. E., Sorribas, M., Luccini, E., de Frutos, A., Berjón, A., and de la Morena, B.: Modified calibration procedures for a Yankee Environmental System UVB-1 biometer based on spectral measurements with a Brewer spectrophotometer, Photochem. Photobiol., 82, 508-514, 2006.

WMO-UMAP workshop on broadband UV radiometers. Technical Report 120, Global Atmosphere Watch, 1996.

WMO Report of the WMO-WHO meeting of experts on standardization of UV indices and their dissemination to the public, Technical Report 127, Global Atmosphere Watch, 1998.

\section{ACPD}

\section{Improving the broadband UV radiometers calibration}

M. L. Cancillo et al.

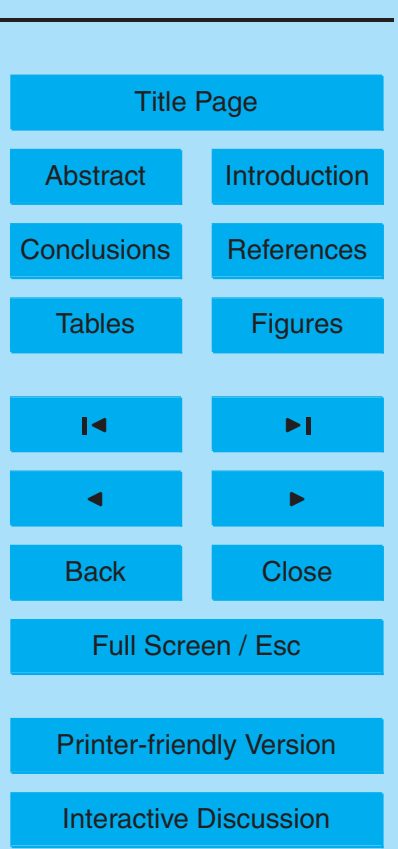




\section{ACPD}

7, 17873-17892, 2007

\section{Improving the broadband UV radiometers calibration}

M. L. Cancillo et al.

Table 1. Calibration factors estimated by the ratio model for the broadband UV radiometers, standard error and root mean square error.

\begin{tabular}{llll}
\hline Radiometer & $C F_{r}\left(\mathrm{~W} / \mathrm{m}^{2} \mathrm{~V}\right)$ & $\mathrm{SE}\left(C F_{r}\right)\left(\mathrm{W} / \mathrm{m}^{2} \mathrm{~V}\right)$ & $\mathrm{RMSE}$ \\
\hline$\# 1$ & 0.1008 & 0.0005 & 0.0070 \\
$\# 2$ & 0.0932 & 0.0003 & 0.0062 \\
$\# 3$ & 0.1051 & 0.0003 & 0.0033
\end{tabular}

Title Page

Abstract

Conclusions

Tables

14

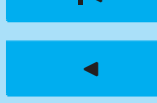

Back

Full Screen / Esc

Printer-friendly Version

Interactive Discussion 


\section{ACPD}

7, 17873-17892, 2007

\section{Improving the broadband UV radiometers calibration}

M. L. Cancillo et al.

Table 2. Calibration factors estimated by the first-order model for the broadband UV radiometers, standard error, root mean square error and coefficient of determination.

\begin{tabular}{lllll}
\hline Radiometer & $C F_{f}\left(\mathrm{~W} / \mathrm{m}^{2} \mathrm{~V}\right)$ & $\mathrm{SE}\left(C F_{f}\right)\left(\mathrm{W} / \mathrm{m}^{2} \mathrm{~V}\right)$ & $\mathrm{RMSE}\left(\mathrm{W} / \mathrm{m}^{2}\right)$ & $R^{2}$ \\
\hline$\# 1$ & 0.1074 & 0.0003 & 0.0053 & 0.995 \\
$\# 2$ & 0.0987 & 0.0003 & 0.0046 & 0.996 \\
$\# 3$ & 0.1059 & 0.0002 & 0.0032 & 0.998 \\
\hline
\end{tabular}

Title Page

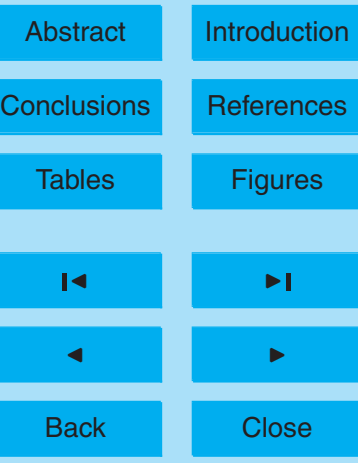

Full Screen / Esc

Printer-friendly Version

Interactive Discussion 


\section{ACPD}

7, 17873-17892, 2007

\section{Improving the broadband UV radiometers calibration}

M. L. Cancillo et al.

Table 3. Calibration factors estimated by the second-order model for the broadband UV radiometers, standard error, root mean square error and the coefficient of determination.

\begin{tabular}{lllllll}
\hline Radiometer & $C F_{s 1}$ & $\mathrm{SE}\left(C F_{s 1}\right)$ & $C F_{s 2}$ \\
$\mathrm{~W} / \mathrm{m}^{2} \mathrm{~V}$ & $\mathrm{~W} / \mathrm{m}^{2} \mathrm{~V}$ & $\mathrm{~W} / \mathrm{m}^{2} \mathrm{~V}^{2}$ & $\begin{array}{l}\mathrm{SE}\left(C F_{s 2}\right) \\
\mathrm{W} / \mathrm{m}^{2} \mathrm{~V}^{2}\end{array}$ & $\begin{array}{l}\mathrm{RMSE} \\
\mathrm{W} / \mathrm{m}^{2}\end{array}$ & $R^{2}$ \\
\hline$\# 1$ & 0.0891 & 0.0010 & 0.0205 & 0.0011 & 0.0042 & 0.997 \\
$\# 2$ & 0.0841 & 0.0008 & 0.0150 & 0.0008 & 0.0036 & 0.998 \\
$\# 3$ & 0.1043 & 0.0007 & 0.0017 & 0.0008 & 0.0032 & 0.998 \\
\hline
\end{tabular}

Title Page

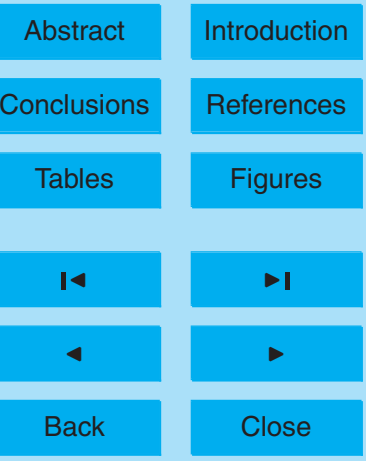

Full Screen / Esc

Printer-friendly Version

Interactive Discussion 


\section{ACPD}

7, 17873-17892, 2007

\section{Improving the broadband UV radiometers calibration}

M. L. Cancillo et al.

Table 4. Calibration factors estimated by the angular model for the broadband UV radiometers, standard error, root mean square error and the coefficient of determination.

\begin{tabular}{lllllll}
\hline Radiometer & $C F_{c 1}$ & $\mathrm{SE}\left(C F_{c 1}\right)$ & $C F_{c 2}$ & $\mathrm{SE}\left(C F_{c 2}\right)$ & $\mathrm{RMSE}$ & $R^{2}$ \\
\hline & $\mathrm{W} / \mathrm{m}^{2} \mathrm{~V}$ & $\mathrm{~W} / \mathrm{m}^{2} \mathrm{~V}$ & $\mathrm{~W} / \mathrm{m}^{2} \mathrm{~V}^{2}$ & $\mathrm{~W} / \mathrm{m}^{2} \mathrm{~V}^{2}$ & $\mathrm{~W} / \mathrm{m}^{2}$ & \\
$\# 1$ & 0.0557 & 0.0013 & 0.0800 & 0.0020 & 0.0028 & 0.999 \\
$\# 2$ & 0.0576 & 0.0011 & 0.0634 & 0.0017 & 0.0025 & 0.999 \\
$\# 3$ & 0.0922 & 0.0016 & 0.0200 & 0.0024 & 0.0030 & 0.998 \\
\hline
\end{tabular}

Title Page

Abstract

Conclusions

Tables

14

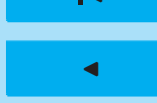

Back
Introduction

References

Figures

-

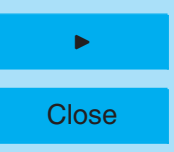

Full Screen / Esc

Printer-friendly Version

Interactive Discussion 


\section{ACPD}

7, 17873-17892, 2007

\section{Improving the broadband UV radiometers calibration}

M. L. Cancillo et al.

Table 5. Comparison of UVER values obtained with angular calibration method and two-steps model (matrix calibration method). Slope values, standard error of the slope, MBE, MABE, and the coefficient of determination are presented.

\begin{tabular}{llllll}
\hline Radiometer & Slope & SE (slope) & MBE (\%) & MABE (\%) & $R^{2}$ \\
\hline$\# 1$ & 0.993 & 0.003 & -2.15 & 2.63 & 0.999 \\
$\# 2$ & 0.952 & 0.001 & +0.61 & 3.21 & 0.999 \\
$\# 3$ & 0.989 & 0.001 & +2.80 & 2.80 & 0.999 \\
\hline
\end{tabular}

Title Page

Abstract

Conclusions

Tables

14

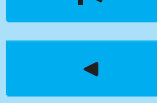

Back
Introduction

References

Figures

-

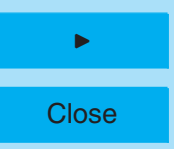

Full Screen / Esc

Printer-friendly Version

Interactive Discussion 


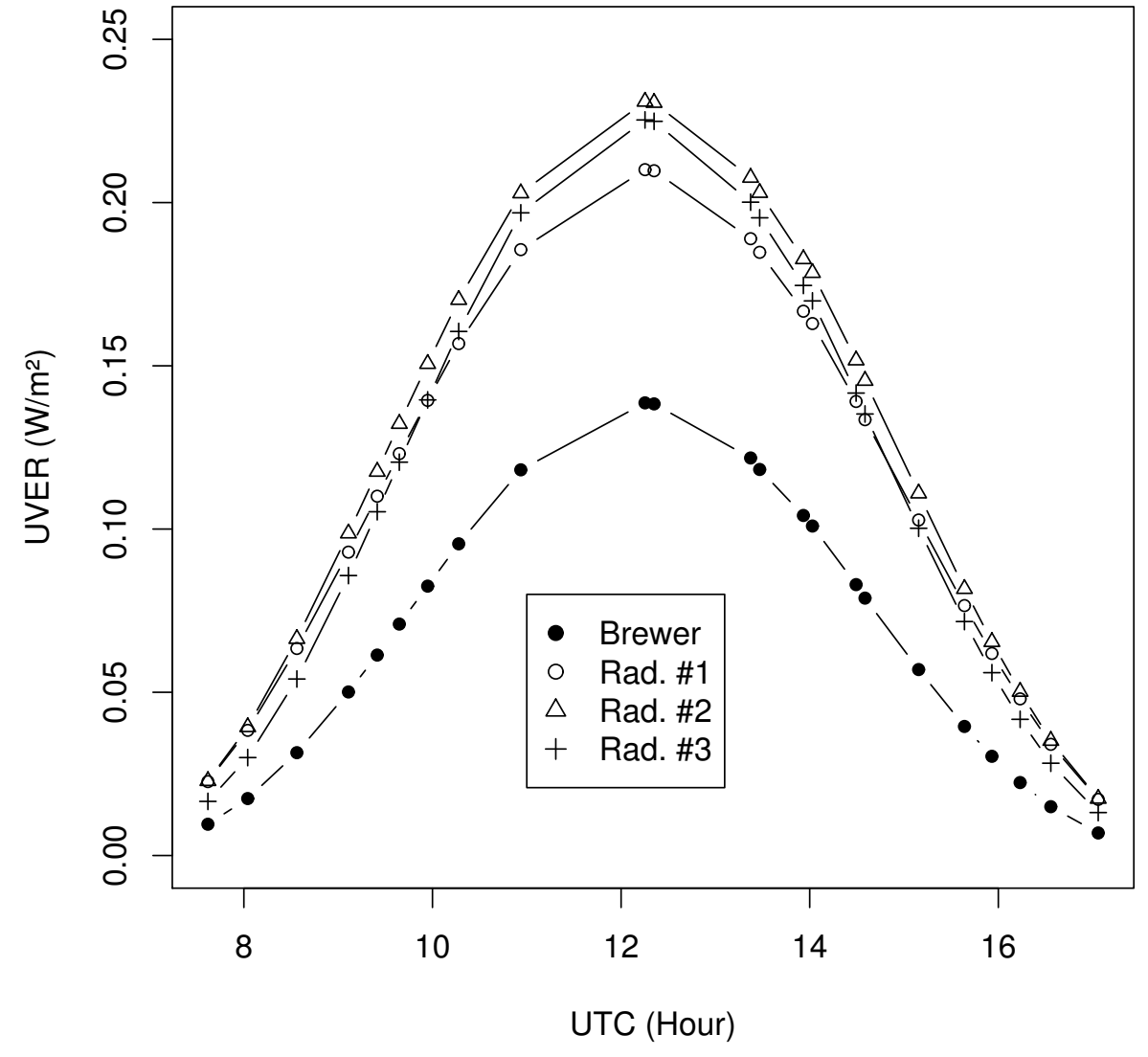

Fig. 1. UVER measurements from the spectroradiometer and the three broadband radiometers with their original calibration, for the 4 October 2005.

\section{ACPD}

7, 17873-17892, 2007

\section{Improving the broadband UV \\ radiometers \\ calibration}

M. L. Cancillo et al.

Title Page

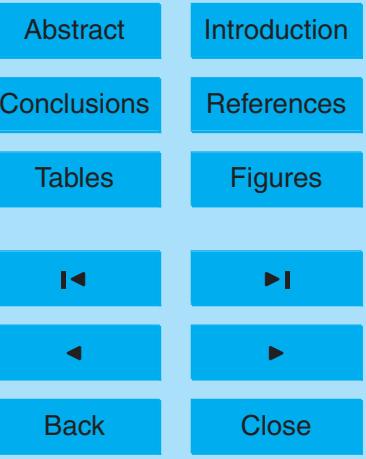

Full Screen / Esc

Printer-friendly Version 


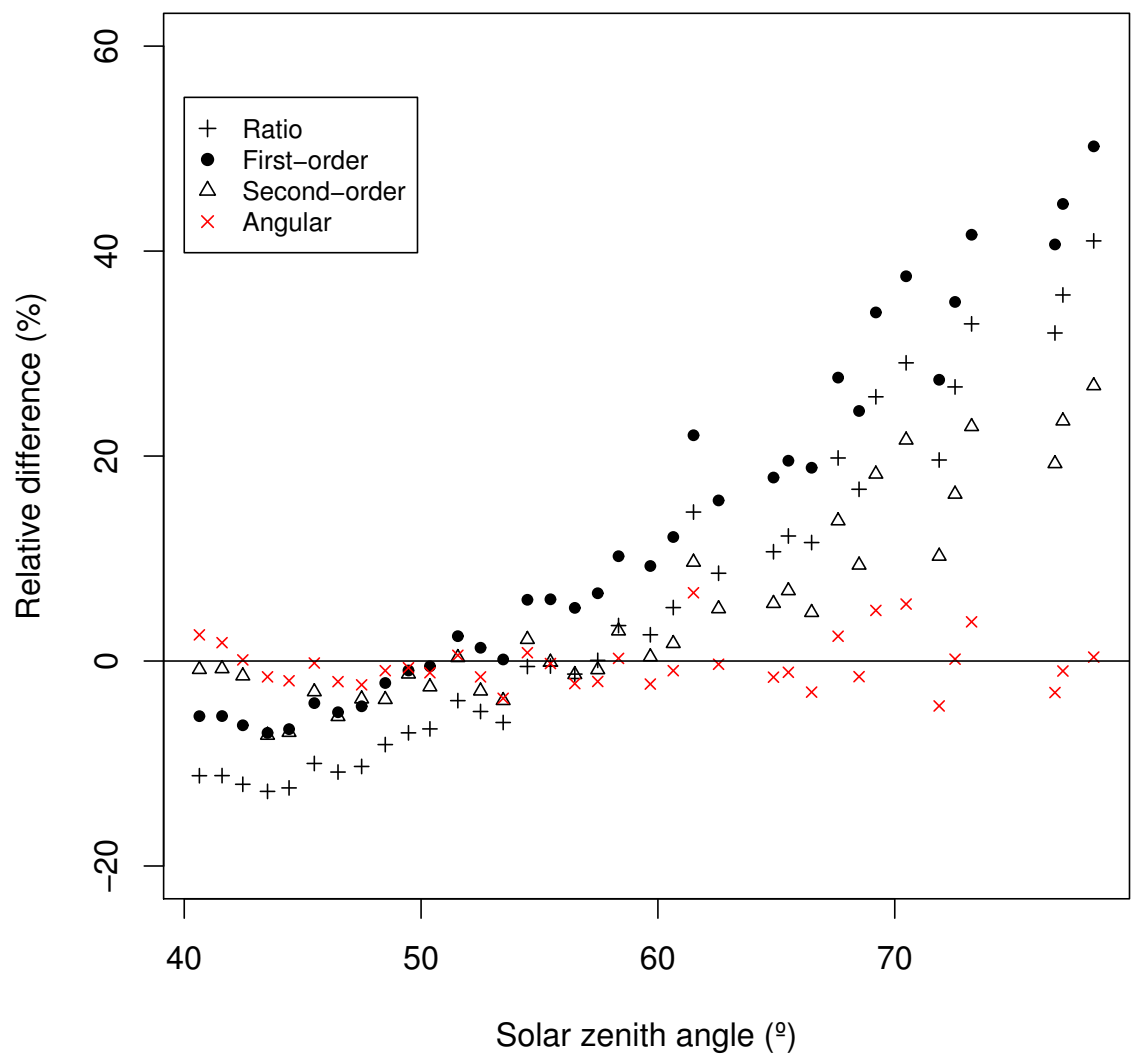

Fig. 2. Relative differences between irradiance measured by Brewer spectrophotometer and estimated by broadband radiometer \#1 using the four one-step models.

\section{ACPD}

7, 17873-17892, 2007

\section{Improving the broadband UV \\ radiometers \\ calibration}

M. L. Cancillo et al.

Title Page

Abstract

Introduction

Conclusions

References

Tables

Figures

14

$\rightarrow$

Back

Close 


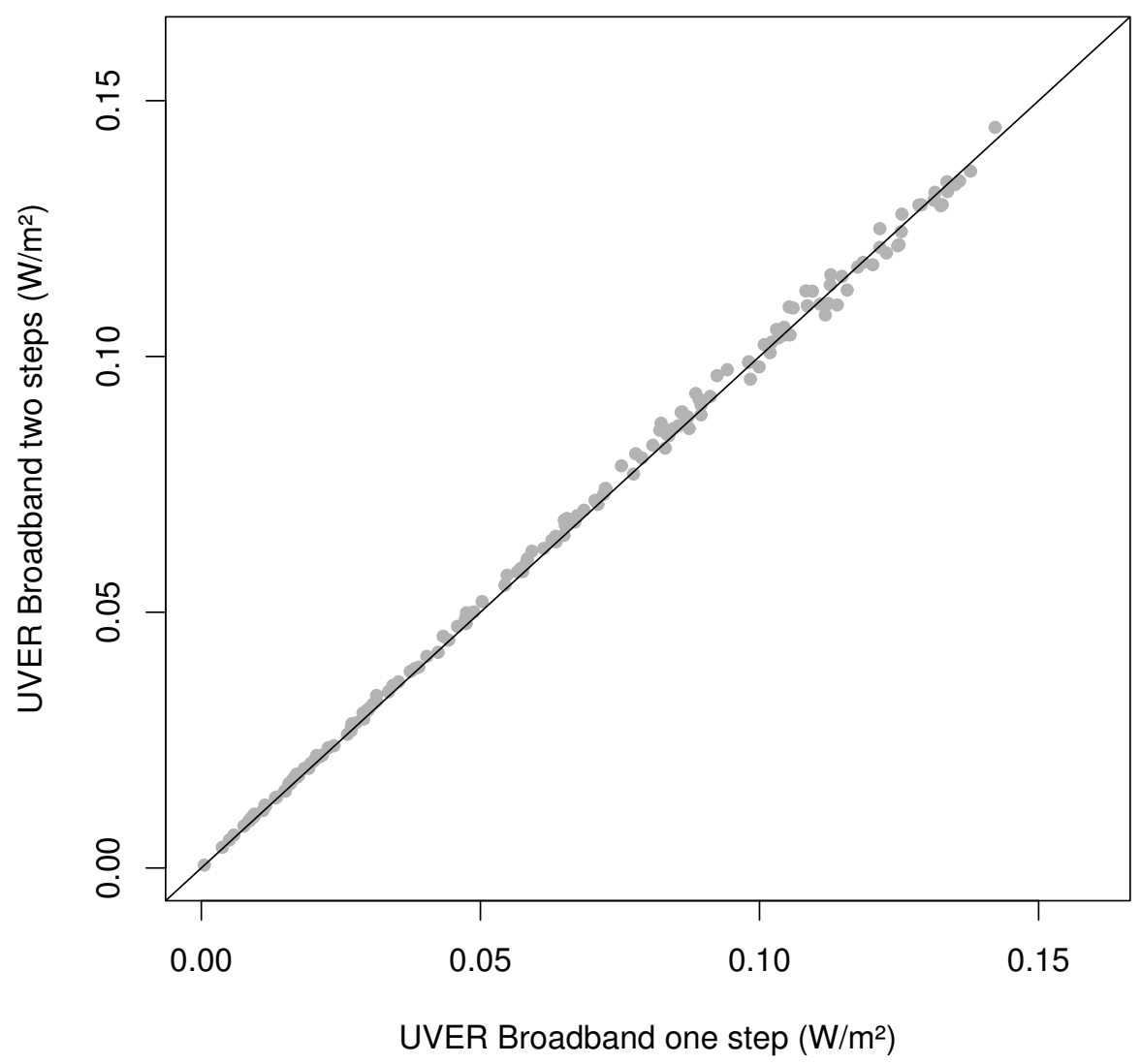

Fig. 3. Comparison of broadband values obtained applying one-step (angular calibration method) and two-steps methods (matrix calibration method) for radiometer \#1.

\section{ACPD}

7, 17873-17892, 2007

\section{Improving the broadband UV \\ radiometers \\ calibration}

M. L. Cancillo et al.

Title Page

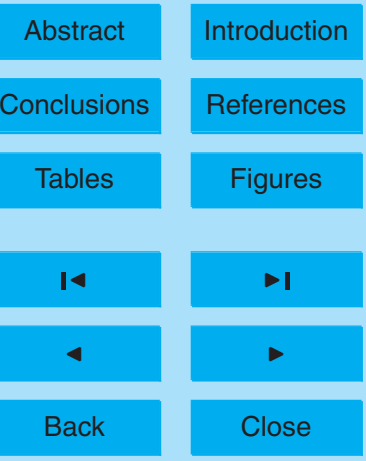

Full Screen / Esc

Printer-friendly Version

Interactive Discussion 